\title{
Differences and similarities of multisystem inflammatory syndrome in children, Kawasaki disease and macrophage activating syndrome due to systemic juvenile idiopathic arthritis: a comparative study
}

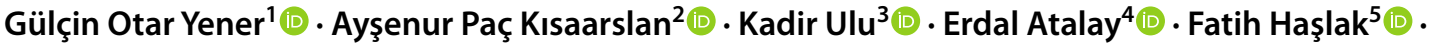

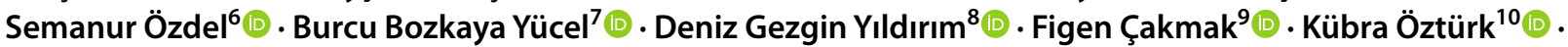

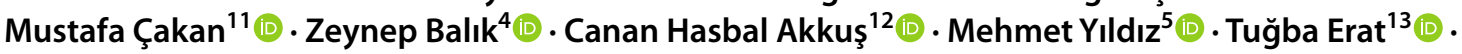

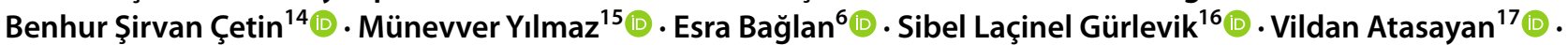

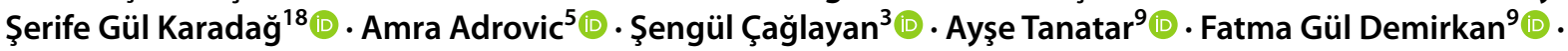

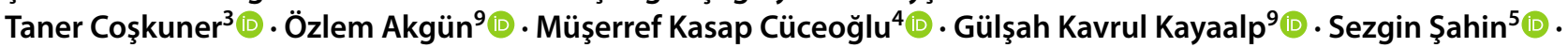

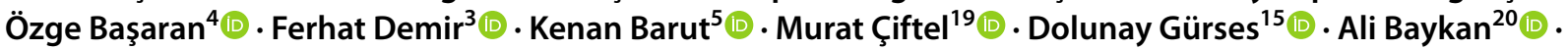

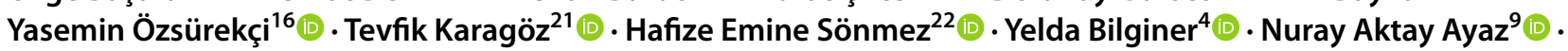

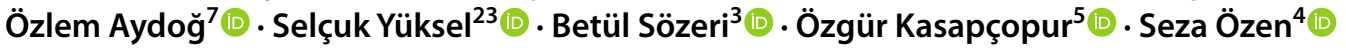

Received: 6 July 2021 / Accepted: 26 August 2021 / Published online: 7 September 2021

(c) The Author(s), under exclusive licence to Springer-Verlag GmbH Germany, part of Springer Nature 2021

\begin{abstract}
To compare the clinical and laboratory findings of multisystem inflammatory syndrome in children (MIS-C), patients with Kawasaki disease (KD) and with macrophage activating syndrome due to systemic juvenile idiopathic arthritis (sJIA-MAS) on real-life data. Patients diagnosed with MIS-C, KD, and sJIA-MAS from 12 different centers in Turkey who were followed for at least 6 months were included in the study. Demographic, clinical, and laboratory findings of all patients were analyzed. A total of 154 MIS-C, $59 \mathrm{KD}$, and 31 sJIA-MAS patients were included. The median age of patients with MIS-C were higher than those with KD while lower than those with sJIA-MAS (8.2, 3, 12 years, respectively). Myalgia (39.6\%), cardiac (50.6\%), gastrointestinal (72.7\%), and neurological (22.1\%) involvements were more common in patients with MIS-C compared to others. MIS-C patients had lower levels of lymphocyte (950 vs 1700 cells/ $\mu$ l) and thrombocyte (173,000 vs 355,000 cells/ $\mu \mathrm{l})$ counts and higher pro-BNP (1108 vs $55 \mathrm{pg} / \mathrm{ml})$ levels than KD. Ferritin levels were higher in patients with MIS-C compared to patients with KD while they were lower than patients with sJIA-MAS (440, 170, 10,442 ng/ml, respectively). Patients with MIS-C had a shorter duration of hospitalization than sJIA-MAS $(p=0.02)$ while they required intensive care unit admission more frequently ( 55 vs 8 patients, $p<0.001$ ). The median MAS/sJIA score of MIS-C patients was -1.64 ( -5.23 to 9.68$)$ and the median MAS/sJIA score of sJIA-MAS patients was -2.81 ([-3.79] to [-1.27]). MIS-C patients displayed certain differences in clinical and laboratory features when compared to KD and sJIA-MAS. Definition of the differences and similarities between MIS-C and the other intense inflammatory syndromes of childhood such as KD and MAS will help the clinicians while making timely diagnosis.
\end{abstract}

Keywords Multisystem inflammatory syndrome in children (MIS-C) $\cdot$ Kawasaki disease (KD) $\cdot$ Macrophage activation syndrome $\cdot$ Systemic juvenile idiopathic arthritis

\section{Introduction}

Gülçin Otar Yener

gulcinotar@gmail.com

Extended author information available on the last page of the article
Severe Acute Respiratory Syndrome Coronavirus type 2 (SARS-CoV-2) was first defined in Wuhan, Hubei province, China as a cluster of unexplained pneumonia in December 2019 [1]. Subsequently, it became a global health problem and the World Health Organization (WHO) accepted this outbreak as a pandemic disease called Coronavirus disease 
19 (COVID-19). Children infected with COVID-19 have usually a mild or asymptomatic course and account for only $1-5 \%$ of patients [2]. At the end of April 2020, a newly recognized syndrome was defined with severe multisystem inflammation in children with clinical features similar to those found in classic Kawasaki disease (KD) and toxic shock syndrome in countries affected by SARS-CoV-2 [3-6]. This novel disease was initially named pediatric inflammatory multisystem syndrome temporally associated with SARS-CoV-2 (PIMS-TS) and a guide was published to raise awareness among clinicians by the Royal College of Pediatrics and Child Health in the United Kingdom [7]. Later, WHO and the Centers for Disease Control and Prevention (CDC) in the USA named this novel disease as multisystem inflammatory syndrome in children (MIS-C) and defined diagnostic criteria $[8,9]$. MIS-C was defined as: age of younger than 21 years, fever (body temperature, $>38.0^{\circ} \mathrm{C}$ ) or report of subjective fever lasting at least $24 \mathrm{~h}$, serious illness leading to hospitalization, laboratory evidence of inflammation, multisystem organ involvement (i.e., involving at least two systems), and laboratory-confirmed SARSCoV-2 infection (positive SARS-CoV-2 real-time reverse transcriptase polymerase chain [RT-PCR] or antibody test during hospitalization) or an epidemiologic link to a person with COVID-19 $[8,9]$.

MIS-C resembles two of the intense inflammatory syndromes we know well in pediatric rheumatology $[10,11]$. Fever and certain manifestations are comparable in patients with MIS-C and KD, whereas the cytokine storm reflected in the laboratory findings of patients with MIS-C resembles macrophage activating syndrome (MAS) [12, 13]. Both the clinical and laboratory features of MIS-C may mimic infectious or autoinflammatory diseases [11-15].

In our rheumatology practice, although MIS-C patients are increasing day by day, there were cases finally diagnosed with KD and MAS during the same period. Therefore, displaying the major clinical and laboratory differences of MIS-C is critical for making a proper differential diagnosis. The studies comparing MIS-C with classical KD [5, 6, 16-20] or MAS [20, 21] are restricted with small sample sizes.

Herein, in this nationwide multicenter cohort, we aimed to evaluate patients diagnosed with MIS-C and subsequently to compare their clinical and laboratory findings with those of patients previously diagnosed with KD and MAS secondary to systemic juvenile idiopathic arthritis (sJIA-MAS). Undoubtedly, COVID-19 and MIS-C will continue to be a problem in the coming months or years. Demonstrating the differences between these three diseases may help clinicians to make timely diagnosis and appropriate management.

\section{Materials and methods}

This cross-sectional study between May, 2020 and May, 2021 was accomplished in 12 pediatric rheumatology centers across Turkey. Patients with MIS-C and a control group concerning patients diagnosed with KD or sJIA-MAS were included in the study. Patients with KD were diagnosed during the study period while patients with sJIA were diagnosed previously but developed MAS during the study period. The patients who did not have the results of SARS-CoV-2 polymerase chain reaction (PCR) and antibody tests were excluded. All data were collected retrospectively from the medical records.

The diagnostic criteria of CDC and WHO were used to define patients with MIS-C [8,9]. An epidemiologic link was defined as exposure to a person with suspected COVID-19 within 4 weeks before the onset of MIS-C symptoms. SARSCoV-2 polymerase chain reaction (PCR) and SARS-CoV-2 antibody [immunoglobulin ( $\mathrm{Ig}$ ) $\mathrm{M}$ and $\mathrm{IgG}$ ] were tested for all patients diagnosed with MIS-C, KD and sJIA-MAS, as well. Standardized SARS-CoV-2 PCR (Bio-Speedy ${ }^{\circledR}$ SARSCoV-2N RT-qPCR kit) and SARS-CoV-2 serological tests such as rapid antibody tests that detect ELISA or IgM/IgG were performed according to the protocols provided by the manufacturer in accredited testing laboratories.

Complete and incomplete KD were identified according to the American Heart Association (AHA) definition [22]. Interpretation of the coronary artery z-score was made according to AHA guidelines [22]. Cardiac dysfunction/ depression was defined as an ejection fraction $<55 \%$ or as a fractional shortening $<45 \%$. Kawasaki disease shock syndrome (KDSS) was described based on systolic hypotension for age, a decrease in systolic blood pressure from a baseline of $\geq 20 \%$, or clinical signs of poor perfusion [23]. The patients were defined as being IVIG resistant if they had persistent or recurrent fever at least $36 \mathrm{~h}$ after completion of the first IVIG dose [23]. Patients who were diagnosed with sJIA previously and developed MAS during the study period were included to the study.

The diagnoses of sJIA and MAS were made according to the International League of Associations for Rheumatology (ILAR) criteria [24] and MAS classification criteria [25], respectively. The MAS/sJIA (MS) score was calculated in all patients [26]. The MS score ranges from -8.4 to 41.8 and consists of seven variables: central nervous system dysfunction, hemorrhagic manifestations, active arthritis, platelet count, fibrinogen, lactate dehydrogenase, and ferritin. The cut-off value $\geq-2.1$ discriminates MAS from active sJIA and was used to measure the severity of inflammation. 


\section{Clinical and laboratory evaluation}

Complete blood count (CBC), albumin, aspartate aminotransferase (AST), alanine aminotransferase (ALT), sodium, urea, creatinine, C-reactive protein (CRP), erythrocyte sedimentation rate (ESR), ferritin, procalcitonin, prothrombin time (PT), activated partial thromboplastin time (APTT), D-dimer, fibrinogen, troponin-I, pro-B-type natriuretic peptide (BNP) levels and echocardiogram findings were recorded from the medical files of the patients. Reference values for laboratory tests were based on the mean age of the whole study population.

Cardiac features were recorded as positive in the presence of any echocardiogram findings: Pericarditis, depressed ejection fraction, valvular dysfunction/valvulitis, coronary dilation, or coronary aneurysm.

Medical treatment and intensive care unit (ICU) support (inotropic agents, oxygen therapy, invasive mechanical ventilation, therapeutic plasma exchange, and extracorporeal membrane oxygenation) applied to the patients were recorded separately.

Study approval and participant consent were obtained from all centers participating in the study and finally, the study was approved by the local ethical board (University of Health Sciences, Umraniye Research and Training Hospital, number: B.10.1.TKH.4.34.H.GP.0.01/400, approval date: December 24, 2020).

\section{Statistical analysis}

Statistical analyses were performed using the SPSS software version 21 . The variables were investigated using visual (histogram, probability plots) and analytic methods (Kolmogorov-Smirnov) to determine whether they are normally distributed. The data of descriptive analysis were expressed as mean-standard deviation (SD) or median; minimum-maximum where appropriate. Categorical variables were compared with the chi-square test or Fisher's exact test where appropriate. The Kruskal-Wallis test was used to compare the continuous data between groups. The Mann-Whitney $U$-test was performed to test the significance of differences using Bonferroni correction to adjust for multiple comparisons.

\section{Results}

\section{Study population}

A total of 154 patients diagnosed with MIS-C participated in the study. As a control group, 59 patients diagnosed with
KD and 31 patients with sJIA-MAS were included. Among 154 patients with MIS-C, 101 (65.6\%) were male and 53 $(34.4 \%)$ were female with a median age of $8.2(1-20)$ years.

Eighteen of 154 patients with MIS-C had a concomitant disease (neurologic disease $=5$, renal diseases $=3$, endocrine diseases $=3$, asthma $=2$, familial Mediterranean fever $=2$, chronic granulomatous disease $=1$, adenosine deaminase 2 deficiency $=1$, and juvenile dermatomyositis $=1$ ).

\section{SARS-CoV-2 test results}

One hundred and nine (70.8\%) patients had a history of contact with COVID-19 patients in the last four weeks. At the time of diagnosis; SARS-CoV-2 PCR was positive in 16 (10.4\%) patients and 129 patients $(83.8 \%)$ were positive for SARS-CoV-2 IgG or IgM.

\section{Clinical features of MIS-C patients}

Fever was the major symptom ( $n=154,100 \%)$, followed by gastrointestinal $(n=112,72.7 \%)$ and cardiovascular manifestations $(n=78,50.6 \%)$. The median duration of fever before the diagnosis was $1(1-4)$ days and the median duration of fever during the follow-up was 5 (2-14) days. The clinical features of patients with MIS-C are depicted in Table 1.

\section{Laboratory investigation of MIS-C patients}

At admission, 113 (73.4\%) patients had lymphopenia and $58(37.7 \%)$ had thrombocytopenia. One hundred forty-nine patients (96.7\%) had elevated levels of CRP while ESR was elevated in 99 (64.3\%) and ferritin in $75(48.7 \%)$ patients. Procalcitonin was increased in 101 (99.1\%) of 102 tested patients. Hyponatremia and hypoalbuminemia were detected in 90 (58.4\%) and 107 (69.4\%) patients, respectively. Of 67 patients tested for Pro-BNP and troponin-I, 63 (94\%) had increased levels of pro-BNP and 19 (28.3\%) had increased levels of troponin-I. The D-dimer test was performed in all the cases with MIS-C and it was elevated in 63 (40.9\%) patients.

Of 78 patients evaluated by chest radiograph and pleural effusion was detected in $12(15.3 \%)$ patients. Among $44(28.6 \%)$ patients who underwent thorax computerized tomography (CT), 9 (20.4\%) had pleural effusion, 18 (41\%) had ground-glass opacities and 17 (38.6\%) had no abnormal findings. Of 49 (31.8\%) patients evaluated by abdominal CT, and bowel edema was detected in 7 (14.2\%) and cholecystitis in $4(8.1 \%)$ patients.

Pericarditis was detected in $9(5.8 \%)$, myocarditis in 39 (25.3\%), CA dilatation in 25 (16.2\%), CA aneurysm in 2 (1.3\%), and mitral valve insufficiency in $24(15.6 \%)$ patients by echocardiogram examination. 
Table 1 Clinical features of patients diagnosed with multisystemic inflammatory syndrome in children

\begin{tabular}{|c|c|c|c|}
\hline Clinical features & $n(\%)$ & Clinical features & $n(\%)$ \\
\hline Fever & $154(100)$ & Renal involvement & $13(8.4)$ \\
\hline Musculoskeletal symptoms & & Gastrointestinal involvement & \\
\hline Arthralgia & $31(20.1)$ & Abdominal pain & $71(46.1)$ \\
\hline Myalgia & $61(39.6)$ & Diarrhea & $42(27.2)$ \\
\hline Arthritis & $14(9.1)$ & Vomiting & $36(23.3)$ \\
\hline Mucocutaneous findings & & Bleeding (melaena) & $1(0.6)$ \\
\hline Rash (maculopapular) & $93(60.3)$ & Cardiac involvement & \\
\hline Conjunctivitis & $95(61.6)$ & Myocarditis & $39(25.3)$ \\
\hline Cracked and erythematous lips & $80(51.9)$ & Coronary artery dilatation/aneurysm & $25(16.2) / 2(1.3)$ \\
\hline Strawberry tongue & $62(40.3)$ & Mitral insufficiency & $6(3.8)$ \\
\hline $\begin{array}{l}\text { Extremity changes (erythema, induration or desqua- } \\
\text { mation of hands and/or feet }\end{array}$ & $27(17.5)$ & Pericardial effusion & $9(5.8)$ \\
\hline Lymphadenopathy & $53(34.4)$ & Neurologic involvement & \\
\hline Hepatomegaly & $14(9.1)$ & Headache & $9(5.8)$ \\
\hline Splenomegaly & $5(3.2)$ & Irritability-agitation-confusion & $21(13.6)$ \\
\hline Hematological involvement & $36(23.3)$ & Convulsion & $2(1.3)$ \\
\hline Respiratory symptoms (cough or dyspnea) & $62(40.3)$ & Neck stiffness & $2(1.3)$ \\
\hline
\end{tabular}

\section{Treatment of MIS-C patients}

The median time of hospitalization was 8 (2-92) days. Fifty-five (35.7\%) patients were admitted to intensive care unit (ICU) within median 1 (1-10) day after hospitalization. The median time of hospitalization in (ICU) was 5 (1-75) days.

Forty-three (27.9\%) patients required $\mathrm{O}_{2}$ support and $18(11.7 \%)$ patients needed mechanical ventilation. Fiftyfive (35.7\%) patients required inotropic agents. All patients received intravenous immunoglobulin (IVIG) $(2 \mathrm{~g} / \mathrm{kg})$ and $19(12.3 \%)$ patients required a second dose of IVIG. One hundred thirteen patients were treated with methylprednisolone (2 mg/kg/day). Methylprednisolone (10-30 mg/ $\mathrm{kg} /$ day, 1-3 days) was given as an initial treatment in 38 (24.6\%) patients. Steroid treatment was tapered and ceased within a median of 21 (2-60) days. Twenty-five (16.2\%) patients received favipiravir while $2(1.3 \%)$ received remdesivir and 4 (2.6\%) lopinavir. Anti-interleukin (IL)-1 treatment (anakinra) was administered to 47 (30.5\%) patients and anti-IL-6 (tocilizumab) to 4 (2.6\%) patients. Furthermore, therapeutic plasma exchange was applied to $27(17.5 \%)$ patients and only one $(0.6 \%)$ patient required extracorporeal membrane oxygenation. Seventeen (11\%) patients were treated with an anti-inflammatory dose of acetylsalicylic acid (ASA) (40-80 mg/kg/day) while 111 (72\%) patients were treated with prophylactic low-molecular-weight heparin (LMWH) $(1 \mathrm{mg} / \mathrm{kg} /$ day $)$ and all of them were discharged with ASA (3-5 mg/kg/day).

\section{Outcomes of MIS-C patients}

The ferritin levels declined to $25 \%$ of the initial values within a median of 6.5 days and to $50 \%$ within a median of 9 days. The lymphocyte counts increased to over $1000 \mathrm{~mm}^{3}$ within a median of 4.5 days and to over $1500 \mathrm{~mm}^{3}$ within a median of 5.5 days. In the median of 6.5 and 10 days, the neutrophil counts and CRP values came to normal, respectively. Five patients (3.2\%) died due to MIS-C.

Laboratory findings of MIS-C patients at the firstmonth control after discharge were summarized in Table 2.

Table 2 The laboratory findings of multisystem inflammatory syndrome in children patients at the first-month control after discharge

\begin{tabular}{|c|c|}
\hline Parameters & Patients $(n=149)$ \\
\hline White blood counts $(\text { cells } / \mu \mathrm{l})^{\mathrm{a}}$ & $8340(4060-19,600)$ \\
\hline Lymphocyte counts (cells/ $\mu \mathrm{l})^{\mathrm{a}}$ & $3350(1370-9360)$ \\
\hline Neutrophil counts $(\text { cells } / \mu \mathrm{l})^{\mathrm{a}}$ & $4130(1840-16,100)$ \\
\hline Platelet counts $(\text { cells } / \mu \mathrm{l})^{\mathrm{a}}$ & $357,000(150,000-652,000)$ \\
\hline Hemoglobin, g/dL & $12.8(9.8-14.7)$ \\
\hline C-reactive protein $(0-5 \mathrm{mg} / \mathrm{l})^{\mathrm{a}}$ & $1.1(0.8-20)$ \\
\hline Ferritin $(7-140 \mathrm{ng} / \mathrm{ml})^{\mathrm{a}}$ & $48(5-859)$ \\
\hline Albumin $(3.8-5.4 \mathrm{~g} / \mathrm{dL})^{\mathrm{a}}$ & $4.3(3.6-4.6)$ \\
\hline Aspartate aminotransferase $(5-32 \mathrm{U} / \mathrm{L})^{\mathrm{a}}$ & $26(13-44)$ \\
\hline Alanine aminotransferase $(5-33 \mathrm{U} / \mathrm{L})^{\mathrm{a}}$ & $19(10-115)$ \\
\hline D-dimer $(0-0.5 \mu \mathrm{g} / \mathrm{ml})^{\mathrm{a}}$ & $0.3(0.1-1.7)$ \\
\hline $\begin{array}{l}\text { NT-pro- brain natriuretic peptide (pg/ } \\
\text { ml })^{\mathrm{a}}\end{array}$ & $25(7.5-151)$ \\
\hline
\end{tabular}

${ }^{\mathrm{a}}$ Data was expressed as median (minimum-maximum) 
Echocardiogram evaluations were normal in 142 (92.2\%) patients however, six $(3.8 \%)$ had CA dilatation and one (0.6\%) had slightly low EF (55\%) at the first-month control.

\section{Comparison of the clinical and laboratory findings of MIS-C patients with others}

Eighty-three (53.8\%) patients with MIS-C fulfilled the classification criteria of KD. Forty-one $(26.6 \%)$ patients had signs and symptoms of complete KD, while $42(27.2 \%)$ patients had incomplete KD features. Furthermore, 67 (43.5\%) patients presented with KDSS manifestations. In the control group of KD patients, 47 (79.6\%) met the classification criteria for complete KD while $12(20.4 \%)$ were incomplete $\mathrm{KD}$, however none of the KD patients presented with KDSS. MIS-C patients presented with incomplete form and KDSS more commonly compared to the control group of KD patients. Comparison of the clinical and laboratory findings of patients with MIS-C and the others were depicted in Table 3.

Of 154 patients with MIS-C, 28 (18.1\%) met the MAS classification criteria. The median MS score of MIS-C patients was -1.64 ( -5.23 to 9.68$)$ and $71(46.1 \%)$ patients had a $\geq-2.1$ MS score which was the best cut-off value in discriminating MAS from active sJIA. In the sJIA-MAS group, the median levels of MS score was -2.81 ([-3.79] to [-1.27]). MS score was higher $\geq-2.1$ in $14(45.1 \%)$ of patients with sJIA-MAS. None of the patients with sJIAMAS presented with shock.

The median age of patients with MIS-C were higher than those with KD while lower than those with sJIA-MAS $(p<0.001)$. Even though fever was the main feature among all, its duration was longer in patients with sJIA-MAS. Arthritis was more common in patients with sJIA-MAS whereas myalgia was more common in patients with MIS-C than those with KD, sJIA-MAS. Hepatomegaly and splenomegaly were less commonly detected in MIS-C patients compared to patients with sJIA-MAS. Cardiac involvement was significantly more pronounced in patients with MIS-C than patients with KD, sJIA-MAS. Pericarditis was detected in 9 patients with MIS-C, in 4 with KD, and in 4 with sJIAMAS $(p=0.37)$. Myocarditis was a distinctive feature in patients with MIS-C $(n=39)$ compared to patients with KD $(n=0)$ and sJIA-MAS $(n=4)(p<0.001)$. The frequency of CA involvement was $17.5 \%(n=27)$ in patients with MIS-C while it was $20.3 \%(n=12)$ in $\mathrm{KD}(p=0.02)$. Neurological involvement was noticeable in patients with MIS-C compared to those with KD and SJIA-MAS.

Patients with MIS-C had lower levels of lymphocyte and thrombocyte than those with KD while not different than patients with sJIA-MAS. The median level of CRP was higher in patients with MIS-C but ferritin levels were higher in patients with sJIA-MAS. However, patients with MIS-C had higher levels of ferritin compared to patients with KD. Fibrinogen levels of MIS-C patients were higher than those with sJIA-MAS and lower than patients with KD. The levels of D-dimer were higher in MIS-C patients than patients with KD while lower than patients with sJIA-MAS. Patients with MIS-C had significantly higher levels of pro-BNP than patients with KD.

Patients with MIS-C had a shorter period of hospitalization compared to patients with sJIA-MAS $(p=0.02)$ while they required intensive care more frequently $(n=55)$ compared to patients with sJIA-MAS $(n=8)(p<0.001)$. The duration of normalization of ferritin levels, and lymphocyte, and neutrophil counts were similar in between groups.

\section{Discussion}

We compared the clinical and laboratory findings of MIS-C patients with KD and sJIA-MAS patients in a large cohort. We aim to show the differences and similarities between these three disorders that can assist clinicians in making rapid diagnoses and appropriate management decisions. The cardiac, gastrointestinal, neurological involvements and myalgia were more pronounced in MIS-C patients compared to patients with KD and sJIA-MAS. When compared to others, patients with MIS-C had significantly lower lymphocyte counts, higher CRP, ESR, and pro-BNP levels. Furthermore, ferritin levels were higher in patients with MIS-C compared to patients with KD while lower than patients with sJIA-MAS.

Initial reports had shown that children with COVID-19 had a milder or asymptomatic course compared to adults [1]. However, the belief that COVID-19 is milder in children changed with the description of Kawasaki-like findings associated with SARS-CoV-2 in April, 2020 [27].

Subsequently, severe cases with an inflammatory syndrome requiring intensive care were reported increasingly [3, 28, 29]. Verdoni et al. reported that the incidence of Kawasaki-like disease increased 30 -fold in patients infected with SARS-CoV-2 and they also stated that the MIS-C patients were more prone to have higher rates of MAS and KDSS compared to classical KD patients [6]. KDSS, an unusual form of KD, shares many similarities to MIS-C [30]. KDSS usually presents in older ages with a higher rate of myocarditis and elevated levels of inflammatory markers compared to $\operatorname{KD}[23,30]$. According to the literature, KDSS was more frequently observed in MIS-C patients than classic KD patients (7\% vs. 45.8\%) [5, 6, 14-17]. Similarly, in the present study, no KDSS cases were presented among the classic KD patients, while the rate of KDSS was $43 \%$ in MIS-C patients.

Cardiac involvement is common in MIS-C and KD patients while the nature of cardiac findings is quite different. 
Table 3 Comparison of patient groups in terms of clinical and laboratory findings

\begin{tabular}{|c|c|c|c|c|c|c|}
\hline & MIS-C $(n=154)$ & $\mathrm{KD}(n=59)$ & sJIA-MAS $(n=31)$ & $\begin{array}{l}p \text { value } \\
\text { (MIS-C vs } \\
\text { KD) }\end{array}$ & $\begin{array}{l}p \text { value (MIS-C } \\
\text { vs sJIA-MAS) }\end{array}$ & $\begin{array}{l}p \text { value (KD } \\
\text { vs sJIA- } \\
\text { MAS) }\end{array}$ \\
\hline \multicolumn{7}{|l|}{ Demographic findings } \\
\hline $\begin{array}{l}\text { Age at diagnosis, } \\
\text { years }\end{array}$ & $8.2(1-20)$ & $3(0.5-14.5)$ & $12(1-18)$ & $<0.001$ & 0.01 & $<0.001$ \\
\hline Gender (female/male) & $101 / 53$ & $38 / 21$ & $17 / 14$ & 0.87 & 0.25 & 0.37 \\
\hline \multicolumn{7}{|l|}{ Clinical findings } \\
\hline Fever, $n(\%)$ & $154(100)$ & $59(100)$ & $31(100)$ & 0.41 & 0.46 & 0.37 \\
\hline $\begin{array}{l}\text { Duration of fever, } \\
\text { days }\end{array}$ & $5(2-14)$ & $8(3-12)$ & $14(3-60)$ & $<0.001$ & $<0.001$ & $<0.001$ \\
\hline Arthritis, $n(\%)$ & $14(9.1)$ & $2(3.3)$ & $12(38.7)$ & 0.24 & $<0.001$ & $<0.001$ \\
\hline Myalgia, $n(\%)$ & $61(39.6)$ & $12(20.3)$ & $5(16.1)$ & $<0.001$ & 0.01 & 0.62 \\
\hline Rash, $n(\%)$ & $93(60.3)$ & $48(81.3)$ & $25(80.6)$ & 0.004 & $<0.001$ & 0.57 \\
\hline Conjunctivitis, $n(\%)$ & $95(61.6)$ & $54(91.5)$ & $0(0)$ & $<0.001$ & $<0.001$ & $<0.001$ \\
\hline $\begin{array}{l}\text { Cracked and erythe- } \\
\text { matous lips, } n(\%)\end{array}$ & $80(51.9)$ & $46(77.9)$ & $0(0)$ & $<0.001$ & $<0.001$ & $<0.001$ \\
\hline $\begin{array}{l}\text { Strawberry tongue, } \\
n(\%)\end{array}$ & $62(40.3)$ & $43(72.8)$ & $0(0)$ & $<0.001$ & $<0.001$ & $<0.001$ \\
\hline $\begin{array}{l}\text { Extremity changes, } \\
n(\%)\end{array}$ & $27(17.5)$ & $34(57.6)$ & $3(9.7)$ & $<0.001$ & 0.27 & $<0.001$ \\
\hline $\begin{array}{l}\text { Lymphadenopathy, } \\
n(\%)\end{array}$ & $53(34.4)$ & $38(64.4)$ & $6(19.3)$ & $<0.001$ & 0.56 & 0.001 \\
\hline Hepatomegaly, $n(\%)$ & $14(9.1)$ & $1(1.7)$ & $20(64.5)$ & 0.07 & $<0.001$ & $<0.001$ \\
\hline Splenomegaly, $n(\%)$ & $5(3.2)$ & $0(0)$ & $18(58.1)$ & 0.32 & $<0.001$ & $<0.001$ \\
\hline $\begin{array}{l}\text { Cardiac involvement, } \\
n(\%)\end{array}$ & $78(50.6)$ & $16(27.1)$ & $8(25.8)$ & $<0.001$ & $<0.001$ & 0.56 \\
\hline $\begin{array}{l}\text { Gastrointestinal } \\
\text { involvement, } n(\%)\end{array}$ & $112(72.7)$ & $15(25.4)$ & $1(3.2)$ & $<0.001$ & $<0.001$ & 0.009 \\
\hline $\begin{array}{l}\text { Hematologic involve- } \\
\text { ment, } n(\%)\end{array}$ & $36(23.3)$ & $5(8.4)$ & $9(29)$ & $<0.001$ & 0.51 & 0.01 \\
\hline $\begin{array}{l}\text { Renal involvement, } \\
n(\%)\end{array}$ & $13(8.4)$ & $2(3.4)$ & $3(9.7)$ & 0.24 & 0.56 & 0.33 \\
\hline $\begin{array}{l}\text { Neurologic involve- } \\
\text { ment, } n(\%)\end{array}$ & $34(22.1)$ & $5(8.5)$ & $3(9.7)$ & 0.01 & 0.22 & 0.37 \\
\hline \multicolumn{7}{|l|}{ Laboratory findings } \\
\hline $\begin{array}{l}\text { White blood counts } \\
(\text { cells } / \mu \mathrm{l})^{\mathrm{a}}\end{array}$ & $9890(2940-29,900)$ & $14,200(4010-47,760)$ & $11,280(1700-19,760)$ & $<0.001$ & 0.59 & 0.005 \\
\hline $\begin{array}{l}\text { Lymphocyte counts } \\
(\text { cells } / \mu)^{\mathrm{a}}\end{array}$ & $950(200-3740)$ & $1700(830-6870)$ & $1100(190-4300)$ & $<0.001$ & 0.06 & $<0.001$ \\
\hline $\begin{array}{l}\text { Platelet counts } \\
\quad(\text { cells } \mu \mathrm{l})^{\mathrm{a}}\end{array}$ & $\begin{array}{l}173,000(49,000- \\
788,000)\end{array}$ & $\begin{array}{l}355,000(111,000- \\
813,000)\end{array}$ & $\begin{array}{l}176,000(93,000- \\
445,000)\end{array}$ & $<0.001$ & 0.82 & 0.003 \\
\hline Hemoglobin, g/dL & $11(7.5-16.4)$ & $11.2(7.8-13)$ & $9.2(7.1-13.6)$ & 0.67 & 0.02 & 0.01 \\
\hline $\begin{array}{l}\text { C-reactive protein } \\
(\mathrm{mg} / \mathrm{L})^{\mathrm{a}}\end{array}$ & $151(20-327)$ & $64(6.1-250)$ & $100(24-336)$ & $<0.001$ & 0.01 & 0.06 \\
\hline $\begin{array}{l}\text { Erythrocyte sedimen- } \\
\text { tation rate }(\mathrm{mm} / \mathrm{h})^{\mathrm{a}}\end{array}$ & $40(5-97)$ & $57(7-115)$ & $31(5-110)$ & 0.05 & 0.51 & 0.07 \\
\hline Ferritin $(\mathrm{ng} / \mathrm{mL})^{\mathrm{a}}$ & $440(98-30,285)$ & $170(29-1006)$ & $\begin{array}{l}10,442(6440- \\
144,797)\end{array}$ & $<0.001$ & $<0.001$ & $<0.001$ \\
\hline $\begin{array}{l}\text { Procalcitonin (ng/ } \\
\mathrm{mL})^{\mathrm{a}}\end{array}$ & $2.6(0.1-100)$ & $3(0.1-4.3)$ & $0.9(0.05-2.7)$ & $<0.001$ & 0.02 & 0.58 \\
\hline D-dimer $(\mu \mathrm{g} / \mathrm{mL})^{\mathrm{a}}$ & $2.7(1-69)$ & $1.7(0-28)$ & $5.4(0.2-80)$ & 0.03 & 0.12 & 0.02 \\
\hline Fibrinogen $(\mathrm{g} / \mathrm{L})$ & $482(125-768)$ & $644(511-919)$ & $238(121-486)$ & 0.001 & $<0.001$ & $<0.001$ \\
\hline
\end{tabular}


Table 3 (continued)

\begin{tabular}{|c|c|c|c|c|c|c|}
\hline & MIS-C $(n=154)$ & $\mathrm{KD}(n=59)$ & sJIA-MAS $(n=31)$ & $\begin{array}{l}p \text { value } \\
\text { (MIS-C vs } \\
\text { KD) }\end{array}$ & $\begin{array}{l}p \text { value (MIS-C } \\
\text { vs sJIA-MAS) }\end{array}$ & $\begin{array}{l}p \text { value (KD } \\
\text { vs SJIA- } \\
\text { MAS) }\end{array}$ \\
\hline $\begin{array}{l}\text { NT-pro- brain natriu- } \\
\text { retic peptide. (pg/ } \\
\mathrm{mL})^{\mathrm{a}}\end{array}$ & $1108(15-35,000)$ & $55(12-4659)$ & NA & $<0.001$ & NA & NA \\
\hline Albumin $(\mathrm{g} / \mathrm{dL})^{\mathrm{a}}$ & $3.1(1.9-4.3)$ & $3.3(2-4.4)$ & $3.1(1.7-4.7)$ & 0.04 & 0.61 & 0.03 \\
\hline $\begin{array}{l}\text { Aspartate ami- } \\
\text { notransferase }(\mathrm{U} / \mathrm{L})^{\mathrm{a}}\end{array}$ & $32(9-1098)$ & $26(9-949)$ & $68(22-1171)$ & 0.12 & $<0.001$ & $<0.001$ \\
\hline $\begin{array}{l}\text { Alanine aminotrans- } \\
\text { ferase }(\mathrm{U} / \mathrm{L})^{\mathrm{a}}\end{array}$ & $19(8-210)$ & $28(8-822)$ & $48(8-344)$ & 0.01 & 0.02 & 0.18 \\
\hline Urea $(\mathrm{mg} / \mathrm{dL})^{\mathrm{a}}$ & $22(5-162)$ & $11(2-38)$ & $11(2-94)$ & $<0.001$ & 0.001 & 0.12 \\
\hline Creatinine $(\mathrm{mg} / \mathrm{dL})^{\mathrm{a}}$ & $0.4(0.2-2.2)$ & $0.3(0.09-0.8)$ & $0.4(0.2-1.5)$ & 0.16 & 0.76 & 0.16 \\
\hline
\end{tabular}

$M I S-C$ multisystem inflammatory syndrome in children; KD Kawasaki Disease, sJIA systemic juvenile idiopathic arthritis; MAS macrophage activating syndrome; $N A$ not available

${ }^{a}$ Data was expressed as median (minimum-maximum)

Myocarditis is more common in patients with MIS-C than patients with $\mathrm{KD}$ while $\mathrm{CA}$ involvement is more commonly observed in KD compared to MIS-C patients [5, 6, 16-20, 31]. Similar to recent studies, myocarditis was more common while CA involvement was less commonly observed in our MIS-C patients than KD patients. However, the frequency of pericarditis was similar in all groups.

Cherqaoui et al. reported that mucocutaneous signs were less notable in MIS-C [18]. Correspondingly, in our cohort, the cracked and erythematous lips, strawberry tongue, and conjunctivitis were more frequent in KD patients than MIS-C patients. In laboratory work-up, lymphopenia, thrombocytopenia, hyponatremia, and hypoalbuminemia were prominent in MIS-C patients likewise the other studies [5, $6,16-20]$. These differences in the clinical and laboratory findings support that MIS-C and KD are two distinct entities with overlapping clinical characteristics [32, 33].

Macrophage activating syndrome is a severe, potentially life-threatening complication of sJIA. It is characterized by unremitting fever, hepatosplenomegaly, hyperferritinemia, pancytopenia, hepatic dysfunction, coagulopathy, and encephalopathy [34]. Even though most of the laboratory findings in MIS-C suggest a MAS-like cytokine storm, ferritin levels are higher and fibrinogen levels are lower in patients with MAS [20, 21]. During the diagnosis of sJIA, presence of higher levels of ferritin and lower levels of fibrinogen were regarded as early warning signs of an impending MAS [35]. In the study of Pouletty et al. being older than 5 years of age and having ferritin levels $>1400 \mu \mathrm{g} / \mathrm{L}$ were displayed as the best discriminators of severe MIS-C and progressive MAS [16]. Furthermore, with immunological work-up, distinctive features stand out in patients with MIS-C, KD, and MAS. The soluble IL-12, IL-18, and CXCL9 were higher in MAS than MIS-C [20].
Diorio et al. showed that children with MIS-C had higher levels of IL-10 and TNF than patients with COVID-19 [36]. Consiglio et al. reported that markers specifically associated with arteritis such as soluble IL-6, IL-17A, CXCL10, were higher in KD than in MIS-C [37]. These findings are suggestive of a distinct immunological phenotype in MIS-C compared to KD and MAS.

The MS score is a tool that was created for the early determination of MAS in sJIA patients [26]. In the present study, although all MIS-C patients had highly elevated levels of inflammatory markers and $46.1 \%$ of them had MS score $\geq-2.1$, which was the best cut-off value in discriminating MAS from active sJIA, only $18.1 \%$ of MIS-C patients met the classification criteria of MAS. Patients with MIS-C had a shorter duration of hospitalization than patients with sJIA-MAS $(p=0.02)$ while they required intensive care unit admission more frequently than sJIA-MAS $(p<0.001)$ because of myocarditis. Unlike MAS secondary to sJIA or other causes, the overwhelming inflammation in MIS-C is not easily discriminated by laboratory parameters in general, but the life-threatening manifestations of MIS-C are comparable to the features of MAS.

Until now, the data regarding the outcome of MIS-C was limited [4, 13, 18, 38-40]. In the literature, most MIS-C patients had a normal left ventricular function in the echocardiogram at 4-6 weeks $[4,13,18,38,39]$. In the present study, the echocardiogram at the first month was normal in most of the patients while only six patients had CA dilatation and one patient had slightly low EF.

Apart from clinical improvement, it is a matter of interest when laboratory findings will improve. The study of Lee et al. showed that the mean time to 50\% decrease in CRP and ferritin levels were 5.3 days and 13.4 days, respectively [17]. Correspondingly, CRP levels returned to normal levels 
at 10 days in our cohort. However, the time of $50 \%$ decrease in ferritin levels was 9 days, and ferritin levels were still high in some cases in the first month. We observed that ferritin was the latest parameter that normalized in MIS-C.

Our study has some potential limitations. This is crosssectional study from 12 different pediatric rheumatology centers. Antibody tests against SARS-CoV-2 were performed by different techniques depending on the centers; however, the protocols provided by the manufacturer in accredited testing laboratories. We could not collect all laboratory parameters such as IL-6, BNP due to the limitations of some centers. However, it is multicentric and nationwide study comparing MIS-C cases with KD and sJIA-MAS in terms of clinical and laboratory characteristics. To the best of our knowledge, this is the first study evaluating and comparing the clinical and laboratory features of MIS-C patients with KD and sJIA-MAS patients in a large multicenter and nationwide cohort.

\section{Conclusion}

MIS-C is a pediatric rheumatic emergency of SARS-Cov-2 infection. Undoubtedly, COVID-19 and MIS-C will continue to be a problem in the coming months or years. Demonstration of the differences and similarities between MIS-C and the other intense inflammatory syndromes of childhood such as KD and MAS is quite important. The improvement of the knowledge about this new disease and differentiation of it from already known mimickers may guide the clinicians to make timely and accurate diagnosis.

Author contributions All authors whose names appear on the submission. (1) made substantial contributions to the conception or design of the work; or the acquisition, analysis, or interpretation of data; or the creation of new software used in the work; (2) drafted the work or revised it critically for important intellectual content; (3) approved the version to be published; and (4) agree to be accountable for all aspects of the work in ensuring that questions related to the accuracy or integrity of any part of the work are appropriately investigated and resolved. All authors approved the final manuscript as submitted and agree to be accountable for all aspects of the work. Conceptualization/design: Otar-Yener, Ulu, Özdel, Çakmak, Gezgin-Yıldırım, Öztürk, HasbalAkkuş, Erat, Bağlan, Atasayan, Karadağ, Çağlayan, Tanatar, Demirkan, Coşkuner, Akgün, Kavrul-Kayaalp, Demir, Baykan, Sönmez, Bilginer, Aktay-Ayaz, Yüksel, Sözeri, Kasapçopur, Özen. Methodology: Otar-Yener, Ulu, Çakmak, Çakan, Hasbal-Akkuş, Karadağ,Çağlayan, Tanatar, Demirkan, Coşkuner, Akgün, Kavrul-Kayaalp, Demir, Baykan, Sönmez, Aktay-Ayaz, Sözeri. Investigation: Otar-Yener, PaçKisaarslan, Ulu, Atalay, Haşlak, Özdel, Çakmak, Öztürk, Çakan, Hasbal-Akkuş,Balık, Yıldız, Erat, Çetin, Laçinel-Gürlevik, Atasayan, Karadağ, Çağlayan, Tanatar, Demirkan, Coşkuner, Akgün,KavrulKayaalp, Şahin, Demir, Çiftel, Özsürekçi,Baykan, Gürses,Karagöz, Sönmez, Sözeri Supervision/oversight: Öztürk, Çakan, Bağlan, Çiftel, Baykan, Gürses, Sönmez,Karagöz, Bilginer, Aktay-Ayaz, Yüksel, Sözeri, Kasapçopur, Özen. Data curation: Otar-Yener, Paç-Kısaarslan, Ulu,
Haşlak, Bozkaya-Yücel, Gezgin-Yıldırım, Hasbal-Akkuş, Yıldız, Erat, Çetin,Balık, Bağlan,Yılmaz, Çağlayan, Coşkuner, Kasap-Cüceoğlu, Şahin, Adroviç, Demir, Başaran, Barut, Gürses,Bilginer, Aydoğ, Yüksel, Sözeri, Kasapçopur, Özen. Formal analysis: Otar-Yener, Özdel, Demirkan, Sönmez, Aktay-Ayaz. Resources: Otar-Yener, Kısaarslan, Haşlak, Paç-Kısaarslan, Bozkaya-Yücel, Öztürk, Çakan, Yıldız, Atasayan, Karadağ,Tanatar, Kavrul-Kayaalp, Adroviç, Demir, Barut, Çiftel, Gürses, Aydoğ, Yüksel, Sözeri, Kasapçopur. Writing - drafting the initial manuscript: Otar-Yener, Ulu, Bozkaya-Yücel, Çakmak, Öztürk, Balık, Erat, Hasbal-Akkuş, Yıldız, Erat, Bağlan, Karadağ, Çağlayan, Tanatar, Demirkan, Coşkuner, Akgün, Laçinel- Gürlevik, Kasap-Cüceoğlu, Kavrul-Kayaalp, Demir, Özsürekçi, Sönmez. Writing - review or editing of the manuscript: Paç-Kısaarslan, Atalay, Özdel, Gezgin-Yıldırım, Çakan,Çetin,Yılmaz, Atasayan, Çetin, Adroviç, Şahin, Başaran, Barut, Çiftel, Gürses, Baykan, Karagöz, Bilginer, Aktay-Ayaz, Yüksel, Sözeri, Kasapçopur, Özen.

Funding No specific funding was received from any bodies in the public, commercial or not-for-profit sectors to carry out the work described in this article.

Availability of data and material The data underlying this article will be shared on reasonable request to the corresponding author.

Code availability Not applicable.

\section{Declarations}

Conflict of interest The authors declare no conflicts of interest.

Ethics approval Study approval and participant consent were obtained from all centers participating in the study and finally, the study was approved by the local ethical board (ethics approval protocol number: B.10.1.TKH.4.34.H.GP.0.01/400, approval date: December 24, 2020; approving institution: University of Health Sciences, Umraniye Research and Training Hospital).

Consent to participate Informed consent was obtained from legal guardians.

Consent for publication Legal guardians signed informed consent regarding publishing their data.

\section{References}

1. Wu Z, McGoogan JM (2020) Characteristics of and important lessons from the Coronavirus Disease 2019 (COVID-19) outbreak in China: summary of a report of 72314 cases from the Chinese Center for Disease Control and Prevention. JAMA 323(13):12391242. https://doi.org/10.1001/jama.2020.2648

2. Parri N, Lenge M, Buonsenso D (2020) Children with Covid19 in pediatric emergency departments in Italy. N Engl J Med 383(2):187-190. https://doi.org/10.1056/NEJMc2007617

3. Riphagen S, Gomez X, Gonzalez-Martinez C, Wilkinson N, Theocharis P (2020) Hyperinflammatory shock in children during COVID-19 pandemic. Lancet 395(10237):1607-1608. https://doi. org/10.1016/s0140-6736(20)31094-1

4. Belhadjer Z, Méot M, Bajolle F, Khraiche D, Legendre A, Abakka S, Auriau J, Grimaud M, Oualha M, Beghetti M, Wacker J, Ovaert C, Hascoet S, Selegny M, Malekzadeh-Milani S, Maltret A, Bosser G, Giroux N, Bonnemains L, Bordet J, Di Filippo S, Mauran P, Falcon-Eicher S, Thambo JB, Lefort B, Moceri P, 
Houyel L, Renolleau S, Bonnet D (2020) Acute heart failure in multisystem inflammatory syndrome in children in the context of global SARS-CoV-2 pandemic. Circulation 142(5):429-436. https://doi.org/10.1161/circulationaha.120.048360

5. Toubiana J, Poirault C, Corsia A, Bajolle F, Fourgeaud J, Angoulvant F, Debray A, Basmaci R, Salvador E, Biscardi S, Frange P, Chalumeau M, Casanova JL, Cohen JF, Allali S (2020) Kawasakilike multisystem inflammatory syndrome in children during the covid-19 pandemic in Paris, France: prospective observational study. BMJ 369:m2094. https://doi.org/10.1136/bmj.m2094

6. Verdoni L, Mazza A, Gervasoni A, Martelli L, Ruggeri M, Ciuffreda M, Bonanomi E, D’Antiga L (2020) An outbreak of severe Kawasaki-like disease at the Italian epicentre of the SARS-CoV-2 epidemic: an observational cohort study. Lancet 395(10239):1771-1778. https://doi.org/10.1016/s0140-6736(20) 31103-x

7. Guidance: paediatric multisystem inflammatory syndrome temporally associated with COVID-19 (2020). https://www.rcpch.ac.uk/ sites/default/files/2020-05/COVID-19-Paediatric-multisystem-\% 20inflammatory\%20syndrome-20200501.pdf. Accessed 1 May 2020

8. Multisystem inflammatory syndrome in children (MIS-C) associated with coronavirus disease 2019 (COVID-19) (2020). https:// emergency.cdc.gov/han/2020/han00432.asp. Accessed 14 May 2020

9. Multisystem inflammatory syndrome in children and adolescents temporally related to COVID-19 (2020). https://www.who.int/ news-room/commentaries/detail/multisystem-inflammatorysyndrome-in-children-and-adolescents-with-covid-19. Accessed 15 May 2020

10. Ozsurekci Y, Gürlevik S, Kesici S, Akca UK, Oygar PD, Aykac K, Karacanoglu D, Sarıtas Nakip O, Ilbay S, Katlan B, Ertugrul İ, Cengiz AB, Basaran O, Cura Yayla BC, Karakaya J, Bilginer Y, Bayrakci B, Ceyhan M, Ozen S (2021) Multisystem inflammatory syndrome in children during the COVID-19 pandemic in Turkey: first report from the Eastern Mediterranean. Clin Rheumatol 40:3227-3237. https://doi.org/10.1007/s10067-021-05631-9

11. Kabeerdoss J, Pilania RK, Karkhele R, Kumar TS, Danda D, Singh S (2021) Severe COVID-19, multisystem inflammatory syndrome in children, and Kawasaki disease: immunological mechanisms, clinical manifestations and management. Rheumatol Int 41(1):19-32. https://doi.org/10.1007/s00296-020-04749-4

12. Akca UK, Kesici S, Ozsurekci Y, Aykan HH, Batu ED, Atalay E, Demir S, Sag E, Vuralli D, Bayrakci B, Bilginer Y, Ozen S (2020) Kawasaki-like disease in children with COVID-19. Rheumatol Int 40(12):2105-2115. https://doi.org/10.1007/s00296-020-04701-6

13. Abrams JY, Godfred-Cato SE, Oster ME, Chow EJ, Koumans EH, Bryant B, Leung JW, Belay ED (2020) Multisystem inflammatory syndrome in children associated with severe acute respiratory syndrome coronavirus 2: a systematic review. J Pediatr 226:45-54. https://doi.org/10.1016/j.jpeds.2020.08.003

14. Hoste L, Van Paemel R, Haerynck F (2021) Multisystem inflammatory syndrome in children related to COVID-19: a systematic review. Eur J Pediatr 180(7):2019-2034. https://doi.org/10.1007/ s00431-021-03993-5

15. Zhao Y, Yin L, Patel J, Tang L, Huang Y (2021) The inflammatory markers of multisystem inflammatory syndrome in children (MISC) and adolescents associated with COVID-19: a meta-analysis. J Med Virol 93(7):4358-4369. https://doi.org/10.1002/jmv.26951

16. Pouletty M, Borocco C, Ouldali N, Caseris M, Basmaci R, Lachaume N, Bensaid P, Pichard S, Kouider H, Morelle G, Craiu I, Pondarre C, Deho A, Maroni A, Oualha M, Amoura Z, Haroche J, Chommeloux J, Bajolle F, Beyler C, Bonacorsi S, Carcelain G, Koné-Paut I, Bader-Meunier B, Faye A, Meinzer U, Galeotti C, Melki I (2020) Paediatric multisystem inflammatory syndrome temporally associated with SARS-CoV-2 mimicking
Kawasaki disease (Kawa-COVID-19): a multicentre cohort. Ann Rheum Dis 79(8):999-1006. https://doi.org/10.1136/annrh eumdis-2020-217960

17. Fernández-Cooke E, Grasa CD, Domínguez-Rodríguez S, Barrios Tascón A, Sánchez-Manubens J, Anton J, Mercader B, Villalobos E, Camacho M, Navarro Gómez ML, Oltra Benavent M, Giralt G, Bustillo M, Bello Naranjo AM, Rocandio B, Rodríguez-González M, Núñez Cuadros E, Aracil Santos J, Moreno D, Calvo C (2020) Prevalence and clinical characteristics of SARS-CoV-2 confirmed and negative Kawasaki disease patients during the pandemic in Spain. Front Pediatr 8:617039. https://doi.org/10.3389/fped.2020. 617039

18. Cherqaoui B, Koné-Paut I, Yager H, Bourgeois FL, Piram M (2021) Delineating phenotypes of Kawasaki disease and SARSCoV-2-related inflammatory multisystem syndrome: a French study and literature review. Rheumatology (Oxford). https://doi. org/10.1093/rheumatology/keab026

19. Bar-Meir M, Guri A, Godfrey ME, Shack AR, Hashkes PJ, Goldzweig O, Megged O (2021) Characterizing the differences between multisystem inflammatory syndrome in children and Kawasaki disease. Sci Rep 11(1):13840. https://doi.org/10.1038/ s41598-021-93389-0

20. Lee PY, Day-Lewis M, Henderson LA, Friedman KG, Lo J, Roberts JE, Lo MS, Platt CD, Chou J, Hoyt KJ, Baker AL, Banzon TM, Chang MH, Cohen E, de Ferranti SD, Dionne A, Habiballah S, Halyabar O, Hausmann JS, Hazen MM, Janssen E, Meidan E, Nelson RW, Nguyen AA, Sundel RP, Dedeoglu F, Nigrovic PA, Newburger JW, Son MBF (2020) Distinct clinical and immunological features of SARS-CoV-2-induced multisystem inflammatory syndrome in children. J Clin Invest 130(11):5942-5950. https://doi.org/10.1172/jci141113

21. Aydin F, Celikel E, Ekici Tekin Z, Coskun S, Sezer M, Karagol C, Kaplan MM, Tekgoz N, Kurt T, Ozcan S, Kavurt AV, Ozkaya Parlakay A, Celikel Acar B (2021) Comparison of baseline laboratory findings of macrophage activation syndrome complicating systemic juvenile idiopathic arthritis and multisystem inflammatory syndrome in children. Int J Rheum Dis 24(4):542-547. https://doi.org/10.1111/1756-185X.14078

22. McCrindle BW, Rowley AH, Newburger JW, Burns JC, Bolger AF, Gewitz M, Baker AL, Jackson MA, Takahashi M, Shah PB, Kobayashi T, Wu MH, Saji TT, Pahl E (2017) Diagnosis, treatment, and long-term management of kawasaki disease: a scientific statement for health professionals from the American Heart Association. Circulation 135(17):e927-e999. https://doi.org/10.1161/ cir.0000000000000484

23. Kanegaye JT, Wilder MS, Molkara D, Frazer JR, Pancheri J, Tremoulet AH, Watson VE, Best BM, Burns JC (2009) Recognition of a Kawasaki disease shock syndrome. Pediatrics 123(5):e783789. https://doi.org/10.1542/peds.2008-1871

24. Petty RE, Southwood TR, Manners P, Baum J, Glass DN, Goldenberg J, He X, Maldonado-Cocco J, Orozco-Alcala J, Prieur AM, Suarez-Almazor ME, Woo P, International League of Associations for R (2001) International League of Associations for R (2004) International League of Associations for Rheumatology classification of juvenile idiopathic arthritis: second revision, Edmonton. J Rheumatol 31(2):390-392

25. Ravelli A, Minoia F, Davi S, Horne A, Bovis F, Pistorio A, Arico M, Avcin T, Behrens EM, De Benedetti F, Filipovic L, Grom AA, Henter JI, Ilowite NT, Jordan MB, Khubchandani R, Kitoh T, Lehmberg K, Lovell DJ, Miettunen P, Nichols KE, Ozen S, Pachlopnik Schmid J, Ramanan AV, Russo R, Schneider R, Sterba G, Uziel Y, Wallace C, Wouters C, Wulffraat N, Demirkaya E, Brunner HI, Martini A, Ruperto N, Cron RQ, Paediatric Rheumatology International Trials O, Childhood A, Rheumatology Research A, Pediatric Rheumatology Collaborative Study G, Histiocyte S (2016) 2016 Classification criteria for 
macrophage activation syndrome complicating systemic juvenile idiopathic arthritis: a European League against Rheumatism/ American College of Rheumatology/Paediatric Rheumatology International Trials Organisation Collaborative Initiative. Ann Rheum Dis 75(3):481-489. https://doi.org/10.1136/annrh eumdis-2015-208982

26. Minoia F, Bovis F, Davì S, Horne A, Fischbach M, Frosch M, Huber A, Jelusic M, Sawhney S, McCurdy DK, Silva CA, Rigante D, Unsal E, Ruperto N, Martini A, Cron RQ, Ravelli A (2019) Development and initial validation of the MS score for diagnosis of macrophage activation syndrome in systemic juvenile idiopathic arthritis. Ann Rheum Dis 78(10):1357-1362. https://doi. org/10.1136/annrheumdis-2019-215211

27. Jones VG, Mills M, Suarez D, Hogan CA, Yeh D, Segal JB, Nguyen EL, Barsh GR, Maskatia S, Mathew R (2020) COVID19 and Kawasaki disease: novel virus and novel case. Hosp Pediatr 10(6):537-540. https://doi.org/10.1542/hpeds.2020-0123

28. Kwak JH, Lee SY, Choi JW (2021) Clinical features, diagnosis, and outcomes of multisystem inflammatory syndrome in children associated with coronavirus disease 2019. Clin Exp Pediatr 64(2):68-75. https://doi.org/10.3345/cep.2020.01900

29. Son MBF, Murray N, Friedman K, Young CC, Newhams MM, Feldstein LR, Loftis LL, Tarquinio KM, Singh AR, Heidemann SM, Soma VL, Riggs BJ, Fitzgerald JC, Kong M, Doymaz S, Giuliano JS Jr, Keenaghan MA, Hume JR, Hobbs CV, Schuster JE, Clouser KN, Hall MW, Smith LS, Horwitz SM, Schwartz SP, Irby K, Bradford TT, Maddux AB, Babbitt CJ, Rowan CM, McLaughlin GE, Yager PH, Maamari M, Mack EH, Carroll CL, Montgomery VL, Halasa NB, Cvijanovich NZ, Coates BM, Rose CE, Newburger JW, Patel MM, Randolph AG, Overcoming COVID-19 Investigators (2021) Multisystem inflammatory syndrome in children - initial therapy and outcomes. N Engl J Med 385(1):23-34. https://doi.org/10.1056/NEJMoa2102605

30. Lamrani L, Manlhiot C, Elias MD, Choueiter NF, Dionne A, Harahsheh AS, Portman MA, McCrindle BW, Dahdah N (2021) Kawasaki Disease Shock Syndrome versus classical Kawasaki Disease, a meta-analysis and comparison with SARS-CoV-2 Multisystem Inflammatory Syndrome. Can J Cardiol. https://doi. org/10.1016/j.cjca.2021.05.014

31. Mavrogeni SI, Kolovou G, Tsirimpis V, Kafetzis D, Tsolas G, Fotis L (2021) The importance of heart and brain imaging in children and adolescents with Multisystem Inflammatory Syndrome in Children (MIS-C). Rheumatol Int 41(6):1037-1044. https://doi. org/10.1007/s00296-021-04845-Z

32. Haslak F, Karagozlu F, Yildiz M, Adrovic A, Dedeoglu R, Kasapcopur O (2021) Could the increasing concerns regarding the post-COVID-19 symptoms cause Kawasaki disease to be underdiagnosed? Clin Exp Rheumatol 39(1):21-22

33. Felsenstein S, Willis E, Lythgoe H, McCann L, Cleary A, Mahmood K, Porter D, Jones J, McDonagh J, Chieng A, Varnier G, Hughes S, Boullier M, Ryan F, Awogbemi O, Soda G, Duong P, Pain C, Riley P, Hedrich CM (2020) Presentation, treatment response and short-term outcomes in paediatric multisystem inflammatory syndrome temporally associated with SARS-CoV-2 (PIMS-TS). J Clin Med 9(10). https://doi.org/10.3390/jcm91 03293
34. Barut K, Adrovic A, Sahin S, Tarcin G, Tahaoglu G, Koker O, Yildiz M, Kasapcopur O (2019) Prognosis, complications and treatment response in systemic juvenile idiopathic arthritis patients: a single-center experience. Int J Rheum Dis 22(9):16611669. https://doi.org/10.1111/1756-185x.13649

35. Çakan M, Karadağ ŞG, Tanatar A, Ayaz NA (2020) The frequency of macrophage activation syndrome and disease course in systemic juvenile idiopathic arthritis. Mod Rheumatol 30(5):900 904. https://doi.org/10.1080/14397595.2019.1660026

36. Diorio C, Henrickson SE, Vella LA, McNerney KO, Chase J, Burudpakdee C, Lee JH, Jasen C, Balamuth F, Barrett DM, Banwell BL, Bernt KM, Blatz AM, Chiotos K, Fisher BT, Fitzgerald JC, Gerber JS, Gollomp K, Gray C, Grupp SA, Harris RM, Kilbaugh TJ, John ARO, Lambert M, Liebling EJ, Paessler ME, Petrosa W, Phillips C, Reilly AF, Romberg ND, Seif A, SesokPizzini DA, Sullivan KE, Vardaro J, Behrens EM, Teachey DT, Bassiri H (2020) Multisystem inflammatory syndrome in children and COVID-19 are distinct presentations of SARS-CoV-2. J Clin Invest 130(11):5967-5975. https://doi.org/10.1172/jci140970

37. Consiglio CR, Cotugno N, Sardh F, Pou C, Amodio D, Rodriguez L, Tan Z, Zicari S, Ruggiero A, Pascucci GR, Santilli V, Campbell T, Bryceson Y, Eriksson D, Wang J, Marchesi A, Lakshmikanth T, Campana A, Villani A, Rossi P, CACTUS Study Team, Landegren N, Palma P, Brodin P (2020) The immunology of multisystem inflammatory syndrome in children with COVID-19. Cell 183(4):968-981. https://doi.org/10.1016/j.cell.2020.09.016

38. Feldstein LR, Rose EB, Horwitz SM, Collins JP, Newhams MM, Son MBF, Newburger JW, Kleinman LC, Heidemann SM, Martin AA, Singh AR, Li S, Tarquinio KM, Jaggi P, Oster ME, Zackai SP, Gillen J, Ratner AJ, Walsh RF, Fitzgerald JC, Keenaghan MA, Alharash H, Doymaz S, Clouser KN, Giuliano JS Jr, Gupta A, Parker RM, Maddux AB, Havalad V, Ramsingh S, Bukulmez H, Bradford TT, Smith LS, Tenforde MW, Carroll CL, Riggs BJ, Gertz SJ, Daube A, Lansell A, Coronado Munoz A, Hobbs CV, Marohn KL, Halasa NB, Patel MM, Randolph AG, Overcoming C-I, Team CC-R (2020) Multisystem inflammatory syndrome in US children and adolescents. N Engl J Med 383(4):334-346. https://doi.org/10.1056/NEJMoa2021680

39. Başar EZ, Sönmez HE, Öncel S, Yetimakman AF, Babaoğlu K (2021) Multisystemic inflammatory syndrome in children associated with COVID-19: a single center experience in Turkey. Turk Arch Pediatr 56(3):192-199. https://doi.org/10.5152/TurkArchPe diatr.2021.21018

40. Patnaik S, Jain MK, Ahmed S, Dash AK, Ram Kumar P, Sahoo B, Mishra R, Behera MR (2021) Short-term outcomes in children recovered from multisystem inflammatory syndrome associated with SARS-CoV-2 infection. Rheumatol Int. https://doi.org/10. 1007/s00296-021-04932-1

Publisher's Note Springer Nature remains neutral with regard to jurisdictional claims in published maps and institutional affiliations. 


\section{Authors and Affiliations}

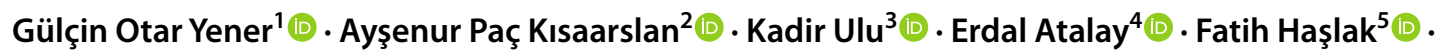

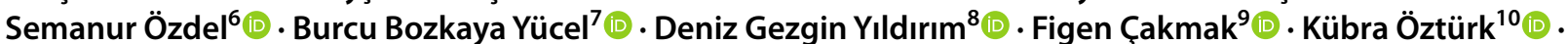

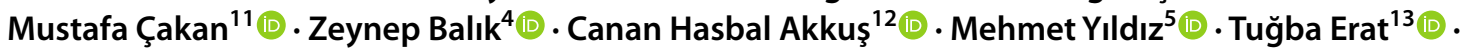
Benhur Şirvan Çetin ${ }^{14}$ (]) Münevver Yılmaz ${ }^{15}$ (1) Esra Bağlan ${ }^{6}$ (1) Sibel Laçinel Gürlevik ${ }^{16}$ () $\cdot$ Vildan Atasayan $^{17}$ (1) .

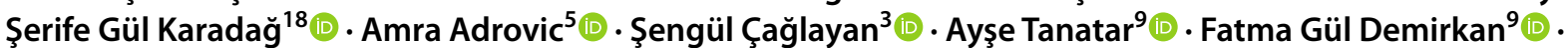

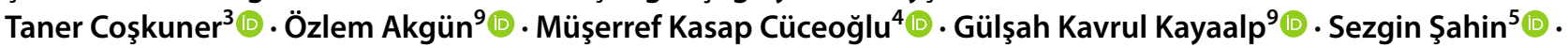

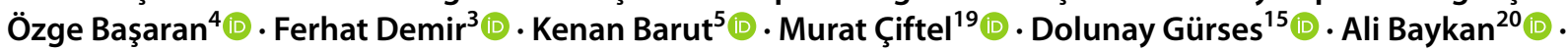

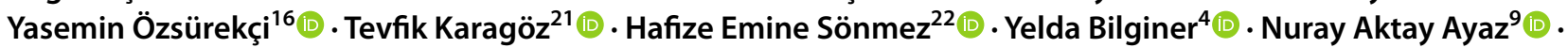

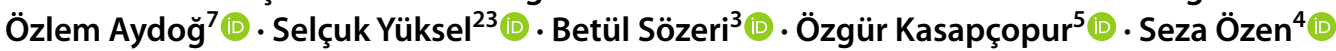

1 Department of Pediatric Rheumatology, Şanlıurfa Research and Training Hospital, Yenice Mah Yenice Yolu No. 1, Sanliurfa, Turkey

2 Pediatric Rheumatology, Faculty of Medicine, Erciyes University, Kayseri, Turkey

3 Pediatric Rheumatology, University of Health Sciences, Ümraniye Research and Training Hospital, Istanbul, Turkey

4 Pediatric Rheumatology, Faculty of Medicine, Hacettepe University, Ankara, Turkey

5 Pediatric Rheumatology, Cerrahpaşa Faculty of Medicine, İstanbul University-Cerrahpaşa, Istanbul, Turkey

6 Pediatric Rheumatology, University of Health Sciences, Dr. Sami Ulus Maternity and Child Health and Diseases Research and Training Hospital, Ankara, Turkey

7 Pediatric Rheumatology, Faculty of Medicine, Ondokuz Mayis University, Samsun, Turkey

8 Pediatric Rheumatology, Diyarbakır Training and Research Hospital, Diyarbakır, Turkey

9 Pediatric Rheumatology, Faculty of Medicine, Istanbul University, Istanbul, Turkey

10 Pediatric Rheumatology, Istanbul Medeniyet University, Göztepe Prof. Dr. Süleyman Yalçın City Hospital, Istanbul, Turkey

11 Pediatric Rheumatology, University of Health Sciences, Zeynep Kamil Women and Children's Diseases Training and Research Hospital, Istanbul, Turkey
12 Pediatrics, University of Health Sciences, Ümraniye Research and Training Hospital, Istanbul, Turkey

13 Pediatric Infectious Diseases, Şanliurfa Research and Training Hospital, Sanliurfa, Turkey

14 Pediatric Infectious Diseases, Faculty of Medicine, Erciyes University, Kayseri, Turkey

15 Pediatric Cardiology, Faculty of Medicine, Pamukkale University, Denizli, Turkey

16 Pediatric Infectious Diseases, Faculty of Medicine, Hacettepe University, Ankara, Turkey

17 Pediatric Cardiology, University of Health Sciences, Ümraniye Research and Training Hospital, Istanbul, Turkey

18 Pediatric Rheumatology, Erzurum Regional Research and Training Hospital, Erzurum, Turkey

19 Pediatric Cardiology, Şanlıurfa Research and Training Hospital, Sanliurfa, Turkey

20 Pediatric Cardiology, Faculty of Medicine, Erciyes University, Kayseri, Turkey

21 Pediatric Cardiology, Faculty of Medicine, Hacettepe University, Ankara, Turkey

22 Pediatric Rheumatology, Faculty of Medicine, Kocaeli University, Kocaeli, Turkey

23 Pediatric Rheumatology, Faculty of Medicine, Pamukkale University, Denizli, Turkey 